() STUDIES ON LANGUAGE CHANGES

\title{
A Tentative Analysis of the Origin of Middle Chinese Grammar and Its Historical Position
}

\author{
Liu Shizhen* Ji Yunxia**
}

\begin{abstract}
Middle Chinese is the language used in the period from the Eastern Han Dynasty to the Sui Dynasty. In recent years researches of Middle Chinese have attracted scholars' attention. While it inherited some characteristics from the grammar of Ancient Chinese, the morphology and syntax of Middle Chinese underwent obvious elimination and new birth, an important content which laid the foundation for the further evolution of the Early Modern Chinese grammar. Numerous grammatical phenomena started to appear in the Tang and Song Dynasties. The grammar was going through a change in which new forms replaced old ones, thus being the mediator in inheriting the archaic and beginning the early modern grammar, and therefore occupying an important position in the history of Chinese.
\end{abstract}

Key words: Middle, Chinese, grammar, origin, historical position

\section{Introduction}

The publication of Ma's Grammar a century ago marked the beginning of the scientific and systematic study on grammar in China. Subsequently, many grammar works, like Junior Chinese Grammar (中等国文典), A History of Chinese Language (国文法草创), and Senior Chinese Grammar (高等国文法) were published. These works, which took classical Chinese as their objects of comprehensive study and covered a long period of time, are what we call the works on classical Chinese Grammar. The 1930s and 1940s saw an important development of research on the Old Chinese grammar from a historical point of view. Scholars began to study Chinese grammar, and some of the most important works are Copulas in the Chinese Grammar by Mr. Wang Li, Explanations on Negatives “弗(fú), 不 (bù)” by Mr. Ding Shengshu, Interpretations of the Two Auxiliaries “在(zài), 著(zhuó)” in Jingde Chuan Deng Lu by Mr. Lü Shuxiang, etc. A new chapter was opened owing to their contributions, especially Lü, who studied the early modern Chinese, and developed a new

\footnotetext{
* Liu Shizhen :Department of Chinese and Literature, Nanjing University, Nanjing, 210093, Jiangsu, China. E-mail: njulsz@163.com.

** Ji Yunxia : School of Foreign Languages, Shandong University, Jinan, 250100, Shandong, China. E-mail: yxji81@163.com.
} 


\section{Liu Shizhen Ji Yunxia}

field of historical grammar study (cf. Xu Jialu, Wang Fuxiang, Liu Runqing, 1996:147). However, as their research was, in a way, far-sighted, there was a lack of historical grammarians, especially in early modern Chinese, and there were practically no achievements in this field before 1949. This changed greatly in the 1950s, when the atmosphere for academic research was stable, and the research on a historical grammar developed greatly and rapidly. As far as monographs are concerned, important works include A Draft about the History of Chinese (Volume II) by Wang Li, Chen Mengjia's A Survey of Yin Ruins Oracle Inscriptions (Chapter III: Grammar), Guan Xiechu's A Grammatical Study on Yin Ruins Oracle Inscriptions, Liu Shiru's A Study on the Quantifiers in the Wei, Jin, Southern-Northern Dynasties, etc. (cf. Guo Xiliang, 1997:36). At the same time, A Historical Grammar of Chinese by Ohta Tatsuo and Papers on Chinese Grammar by Ushijima Tokuji appeared. Although the study stopped for over ten years, owing to the "Cultural Revolution" in the mid-1960s, it started flourishing again at the end of the 1970s, with an increasing number of researchers and achievements.

However, when looking back at over 20 years' of study of the Chinese historic grammar after the "Cultural Revolution", it is not hard to find the weakness in the study of the middle grammar, a transition from the archaic to early modern time. This means that the historical study of the grammar of archaic Chinese and that of early Chinese were thorough and their results abundant, whereas the historical research of Middle Chinese was very poor. It was like a bottleneck in the middle, unhelpful to the establishment of a developmental history of scientific grammar. At the suggestion of professors from Beijing University and Zhejiang University, a symposium on Middle Chinese was held in October, 2000, in which discussions on the significance, contents, methodology, corpus and time-division of Middle Chinese study produced helpful results. It was also agreed that an annual symposium be held every year, to be hosted by the universities in turn, which shows an essential change in Middle Chinese study. To further the study of Middle Chinese grammar, this paper describes the overall situation of Middle Chinese, its origin and its role in the history of Chinese grammar from a macroscopic perspective.

\section{Definition of Middle Chinese grammar}

Middle Chinese grammar, a very important constitutive part in the history of Chinese grammar, belongs to the grammar of the dynastic history. As it is the subject of history, the problem of its division had to be dealt with. In the $2^{\text {nd }}$ symposium on Early Modern Chinese held in Shanghai in 1986, discussions were carried out about its time-delimitation, which continued for a long time after the symposium. The problem had been posed before the researchers of Middle Chinese.

The concept of Middle Chinese was suggested by the famous Swedish sinologist 
Karlgren, who, while studying the history of Chinese phonology, divided Chinese into five periods: Primeval Chinese, Archaic Chinese, Middle Chinese, Early Modern Chinese and Old Mandarin (Karlgren, 1940:21). After that, Wang Li in his A History of Chinese Language adopted the term Middle Chinese, proposing that Middle Chinese should refer to the period from Wei, Jin, Northern and Southern Dynasties to the first half of the Southern Song Dynasty. However, Ohta argued that it also included the period of Wei, Jin, Northern and Southern Dynasties (Ohta Tatsuo, 1991:10). In recent years, Fang Yixin and Wang Yunlu (1993: 1) suggested that Middle Chinese should refer to the period from the Eastern Han Dynasty to Northern and Southern Dynasties. The more popular theory that Middle Chinese covers the period of the Eastern Han Dynasty, Wei, Jin, Northern and Southern and Sui Dynasties ${ }^{\circledR}$ is a somewhat changed version based on the above ideas. Japanese Sinologists used the term 中世汉语(zhōngshì hànyǔ), which had the same meaning as the Chinese term 中古汉语(zhōnggǔ hànyǔ), but the Japanese scholars' delimitation was on the period from the Wei Dynasty, the Jin Dynasty to the end of the Tang Dynasty and the Five Dynasties (Shimura Lyoji, 1995:3).

The time-division of the history of the Chinese language is a problem that should be solved promptly, so that the implications of historical development would be clearer and the characteristics of times more prominent for systemic research. That is the main reason why the time-delimitation need always be made primary in the research on language from the perspective of dynastic history. However, a scientific and concise division must be based on an extensive study and the inherent law of language development, and as our study is still at an early stage, it will be hard to provide objective evidence for time-delimitation. There seems to be a cause-effect relationship: linguistic researches in dynastic history have to have time-delimitation, and a scientific division must rely on the full study. The idea is to roughly fix the upper and lower limit of Middle Time on the basis of our knowledge of Middle Chinese and then in the course of deep research to revise them again and again in order to meet the reality of Middle Chinese. In fact, this is the very process used for research on Early Modern Chinese. After the symposium on Early Modern Chinese, the problem of time-delimitation has not yet been fully solved, and is now still under discussion. However, the study of Modern Chinese is flourishing and the achievements of scientific researches in this field abound, which is helpful for determining the time-delimitation for Early Modern Chinese. It can be assumed that this relationship of mutual promotion will continue in the future.

\footnotetext{
(1) The Sui Dynasty started in 581 and ended in 618. The Northern and Southern Dynasties ended in 589, and the gap of 618 and 589 was not up to 30 years, therefore it was not be counted as for the linguistic change.
} 


\section{Liu Shizhen Ji Yunxia}

In Chinese history, the Wei Dynasty, Jin Dynasty, Northern and Southern Dynasties ruled in a chaotic time, when the Han people moved to remote areas and other nationalities advanced into the central part of the country, thus strengthening the mixture of different nationalities, promoting the spread and exchange of cultures, which had a great impact on the development of Chinese language. During this period, evident changes in phonetics, vocabulary and even in grammar took place, in comparison with the past. For this reason, this period should be regarded as the main stage of Middle Chinese. Furthermore, in the literature in China proper, some corpus that to a certain degree represented speech, which had begun to come progressively into the Chinese language at the beginning of the Eastern Han, e.g. the Han-styled Folk Ballads and scattered materials in the works of literati and some plain forms in the Chinese translations of Buddhist Scriptures, which took the colloquial form for preaching them to believers, all had a not insignificant bearing on the then and later language. Therefore, it is possible to take the Eastern Han, with its scattered oral corpus, as the beginning stage for Middle Chinese, and the dynasties of Wei, Jin, the Southern and Northern dynasties, with the oral materials more concentrated and more systemic in the language, as its main-body stage, and thus the whole period of Middle Chinese would cover the dynasties of the Eastern Han, Wei, Jin, Southern and Northern and Sui.

2. The general picture and the origin and development of the grammar of Middle Chinese

The development of grammar with its gradual change, must, in general, be based on the grammar of the previous time, and must influence the later grammar. So the laws of grammar in various times all inherit from former grammatical elements and initiate latter grammar elements, and a history of grammar is to connect various historical times with mutual inheritance. Grammar, however, develops unevenly as a result of factors from both within and without. It sometimes develops more and rapidly, but sometimes slowly, and sometimes apparently but at times covertly. The difference is very natural and helps us to delimit the different periods of grammatical development. Therefore, the development is always closely related to various specific periods of history. Roughly, three kinds of connections can be classified in this study. Firstly, some of the grammatical elements did not appear before this period, but sprouted, developed during it and disappeared later on. Although this phenomenon was rare, it did reflect what was typical of that time. Secondly, some of them sprouted before this time, and developed during it. The phenomenon reflected the change from quantity to quality, and the elements of the previous grammar were introduced on the basis of inheritance to the grammar of that time. Thirdly, some sprouted during this time, and developed later. This manifested the essential new birth and reflected the initiative function of the grammar at that time for a later grammar. These three 
kinds of evolution to various degree are the key points in the research of the historical position of grammar in a certain specific period.

The characteristics of the grammar in Middle Time, where the dynasties of Wei, Jin, the Southern and Northern Dynasties are the main stage, are mainly that in this transition time, a large number of old forms were still in use, a few forms disappeared, while new forms came into being progressively, to be consolidated and developed, and their dominance was to be established. So it can be said that the whole period reflected the replacement of old grammatical forms by the new, and the appearance or development and the consolidation and prevalence of many grammatical forms till early modern time, thus laying gradually the foundation of modern Chinese grammar. The sprout and development of these grammatical forms manifested themselves at the same time in the two aspects of morphology and syntax. The main points are cited and their survey explained in the following parts. (See Liu Shizhen, 1992 for more detail).

\subsection{Nouns}

In respect of nouns, there was, in the main, the development of affixes. The prefix “阿 (read as "ā")" appeared in the Eastern Han Dynasty, and was mainly used before names or the character "谁(shuî)" to show intimacy. During the dynasties of Wei, Jin, the Southern and Northern Dynasties, “阿(司)" could be prefixed to surnames, names, one's other names, and birth names, or used before relatives' appellations, or before pronouns, all showing intimacy. The character "子(zî)" tended to be grammaticalized as a suffix in archaic time and was in wide use in Middle Time to indicate people, animals, plants, vessels and other objects. After the dynasties of Tang, Song, its capacity of word-formation was further strengthened. The character "头(tóu)" was grammaticalized as a suffix in the Eastern Han Dynasty, and used often after position nouns or the nouns indicating things in Middle Time. In the dynasties of Tang and Song, this usage was more popular. The grammaticalization of the character "儿(ér)" started in the Eastern Han Dynasty, but there were few examples of further grammaticalization in Middle time. In the Tang dynasty, this usage of “儿(ér)" as a suffix became mature and its capacity of word-formation was also strengthened. Affixes “阿(司), 子(ž̃), 头(tóu), 儿(ér)” were all in use till later time.

\subsection{Verbs}

In respect of verbs, there were, in the main, the development of tense-formation and auxiliaries. In Archaic Chinese, the verb tense was expressed by adverbs: “既(jì), 已(y气̃)” denoting past tense, “方(fāng), 正(zhèng)" etc. present tense, and “将(jiāng), 且(qiě)” etc. future tense. In the Middle time, new forms were developed to indicate past tense and present tense. The verbs expressing the sense of “completeness", e.g. “毕(bì), 竟(jìng), 讫 (qì), 已 (y̌̃), 了(liǎo)” were used after the predicate verbs, acting as complements, to denote the finished action. The verb “著 (zhuó)", meaning "to stick to,to put", was put 


\section{Liu Shizhen Ji Yunxia}

after the predicate verb as a complement to indicate a continuing action. Two new forms of the adverbs “欲 (yù), 要 (yào)” were developed to express the future tense. Originally, the words “毕(bì), 竟(jìng), 论(qì), 已(y̌̃), 了(liǎo)” and “著(zhuó)” were lexical verbs, but when they were put after the predicate verbs as complements, their meanings were partly grammaticalized, only to show an action expressed by the predicate verbs which either finished or continued. Although they were not developed into tense auxiliaries, the movement from the position before the predicate verb to the one after it, and the change from the time modification of action by adverbs as adverbials to result modification of action by grammaticalized verbs as complements, is a very important change indeed. While the tense auxiliaries, like “了(liăo), 着(zhuó)" in modern Chinese, finally came into being in the Tang and Song Dynasties, it was still the result of development on the basis of the above usage during the Middle Time. The development of auxiliaries was seen in these two aspects. Firstly, some auxiliaries expressing possibility, like “堪(kān), 容(róng), 办(bàn), 中(zhòng)" were produced, and “要(yào)” expressing wish and “应(yīng), 合(hé), 须(xū)” expressing obligation were also produced. Secondly, two-syllable auxiliaries appeared, like “容可(róngkě), 容得(róngdé), 办得(bàndé)” denoting possibility,and “当须(dāngxū), 须当(xūdāng), 当应(dāngyīng), 应当(yīngdāng), 宜当(yídāng), 当宜(dāng yí), 宜须 (yíxū), 应须(yīng xū), 宜应(yíyīng), 应合(yīnghé), 要应(yàoyīng), 要须(yàoxū), 要当 (yàodāng), 要宜(yàoyí), 会当(huìdāng), 会应(huìyīng), 会须(huìxū), 必须(bìxū), 必应 (bìyīng), 必宜(bìyí)" denoting obligation, many of which were still in use and were further developed in the Tang and Song Dynasties.

\subsection{Adjectives}

Changes in adjectives lay, in the main, in the use of root-repeated adjectives (AA type) and the appearance of the adjectival suffix “馨( $(x \bar{n})$ )".

There were examples of this kind of adjectives in ancient time, but few at the time researched. However, the examples not only increased, but also gained rhetorical emphasis besides their original descriptive nature. While adjectives were used as attributives or predicates, other modifiers could be inserted between the modified and described nouns, though in ancient time this could not be done. This was especially obvious in poems.

“馨(xīn)” was a new adjective suffix, which could be used after the verb “如(rú)” and its objects, indicating "like......, or used after the demonstrative pronouns “宁(níng), 尔(ěr), 如(rú)” to form phrases “宁馨(níngxīn), 尔馨(ěrxīn), 如馨(rúxīn)” meaning “that way” or "this way". Because the use of the character "馨(xīn)" was not registered before the Jin and Song dynasties, and the character "生(shēng)" was used instead of it after the Tang and Song Dynasties, “馨(xīn)” carries a vivid color of this period of time.

\subsection{Numerals and quantifiers}

The development of numerals can be seen in approximate numbers, ordinal numbers and 
interrogative numerals and zero numerals, and for quantifiers, noun-classifiers and verb-classifiers (cf. Liu Shiru, 1965).

In expressing an approximate number, there were many newly-added forms, some of which used two neighboring numbers, e.g. “十八九(shíbā-jiǔ)” (meaning “about ten”), some using the AABB type, e.g. “十十五五(shíshí-wǔwǔ)" (meaning “about ten”), some using “垂(chuí), 减(jiăn), 向(xiàng), 约(yuē)” before the numeral, the quantifier, or, using “许(xǔ), 强(qiáng)” after the numeral, the quantifier. Furthermore, some special phrases expressing approximate numbers, such as “数四(shùsì), 如干(rúgān)”, were formed. The prefix “第(dì)” in ordinal numbers was fully developed, and the expression “第(dì) + numeral + HEAD", a complete form, was often used. The forms “多少(duōshăo), 几许 (jǐxŭ), 几多(jǐduō)” appeared for interrogative numerals. As for the zero number, “三千三 (sānqiānsān)", which was used in poems, it could express 3,300, which is a different form of expression when compared with the traditional expression, “百五(băiwǔ)” meaning 105.

The development of quantifiers was one of the most typical grammatical phenomena in the Middle Time. Individual quantifiers, which were the core of the quantifier system, indicating the natural unit for an individual thing, developed fully in this time, and in addition about one hundred were newly born. Moreover, their grammatical function went through new developments, i.e. they could be used to form an AA pattern, to be combined with an ordinal number, demonstrative pronoun, or interrogative pronoun. They could also be taken as a root or suffix to form a noun. In addition, the increase of the collective quantifiers, standardization of the measure quantifiers, and the expansion of the domain of a loan word for a temporary quantifier, all reflected the overall maturity of noun-quantifiers. Verbal classifiers were divided into two groups: a special and a loan category. The former were “过(guò), 番(fān), 遍(biàn), 通(tōng), 回(huí), 下(xià), 次(cì), 周(zhōu), 高(zā), 反(făn), 合(hé), 度(dù)”, numbering over ten, while the latter included “声(shēng), 拳 (quán), 口(kǒu), 杵(chǔ), 槌(chuí)” etc., amounting to five or six. Their grammatical function expanded to their combination with ordinal numerals or demonstrative pronouns, a reflection of the maturity of verbal classifiers. In the Middle Time, the mature numerals and quantifiers lay the foundation for further development in the periods of Tang and Song.

\subsection{Pronouns}

There was an obvious development and changes with respect to the personal pronouns, demonstrative pronouns and interrogative pronouns.

The development of the personal pronouns lays, in the main, in four aspects. Firstly, the two first personal pronouns “身(shēn), 侬(nóng)", which were of the features of time and region respectively, were new. Secondly, “汝(rǔ), 尔(ěr)”, terms to address the subordinate and the young by the superior and the old with the emotion of intimacy, were widely used in the Tang Dynasty, giving rise to the second personal pronoun “你(nǐ)”. Thirdly, “其(qí)" 


\section{Liu Shizhen Ji Yunxia}

could be used as a subject or an object, a breakthrough in the constraints imposed in

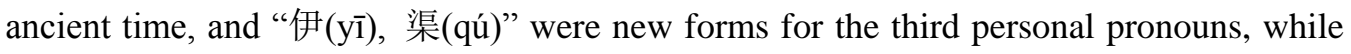
“他(tā)” was also in the state of sprout. All this provided the conditions for their formation and establishment in Tang. Fourthly, the word of analogy appeared, i.e. “比 (bi)", which acted as a self-depreciatory expression and a respectful form of address for the $1^{\text {st }}$ and $2^{\text {nd }}$ person pronouns.

There were three kinds of development for demonstrative pronouns. Firstly, the examples of “尔(ěr)" increased with the common use in demonstration of shapes and states. The character “是(shi)" developed as an indefinite pronoun. Secondly, new demonstrative pronouns, like “阿堵(ādǔ), 宁馨(níngxīn), 尔馨(ěrxīn), 如馨(rúxīn), 许(xǔ), 渠(qú)” appeared. The former four words were of specific for this period, while “许(xǔ)" was specific for the Southern region and referring to both objects and state, shape. This latter usage developed greatly in the Dynasties of Tang and Song. Thirdly, some widely-used demonstrative pronouns in the Tang and Song Dynasties, e.g. “那(nà), 个(gè), 就(jiù)”, which referred to objects, and “能(néng)" which referred to state and shape, were occasionally used in this time ( cf Lü Shuxiang, 1986: 243, 296 ).

There were, in the main, three kinds of development with respect to interrogative pronouns. Firstly, the pronouns “谁(shuí), 何(hé)", which were inherited from ancient time, when they were used to produce new grammatical forms, e.g. “阿(司), 谁(shuí), 何者 (hézhě), 何 等 (héděng), 何物 (héwù), 何所 (hésuǒ), 何如 (hérú), 何似 (hésì), 何当 (hédāng), 那......何(nă......hé......)”, etc., could now express new meanings (Ohta Tatsuo, 1991:69). Secondly, new forms of some interrogative pronouns appeared. They were, for example, the form “那(nă)", which was mainly used to express rhetorical questions, and to enquire reason, manner, place and time, the form “底(dî)", which was roughly the equivalent of “何(hé)" but specific for the Southern region, the form “所(suǒ)", whose examples increased, the form “若(ruò)” which enquired the measure, and the form “若为 (ruòwéi)” which enquired manner. Thirdly, “多少 (duōshăo), 早晚 (zăowăn), 远近 (yuănjìn)", which were relevant to questions formed with two adjectives of positive and negative senses, began to appear. Most of these new types of usage continued in the Tang and Song Dynasties.

\subsection{Adverbs}

As compared with the ancient time, there were three remarkable changes with adverbs. Firstly, one change was the tendency for them to be simplified and regulated: the highly complicated phenomena began to disappear and adverb forms with the same function decreased rapidly. Only one form, “然(rán)", was left in this period with respect to the adverb suffixes which used to be seen in literature. Secondly, a lot of new adverbs, and "自 (zi)" and “复(fü)", two adverb suffixes, appeared in this period. The new adverbs include 
degree adverbs like “偏(piān), 过(guò), 奇(qí), 酷(kù), 差(chà), 熟(shú), 绝(jué)”, which expressed extremity, “更(gèng), 转(zhuăn)" expressing the sense of "more" and “微(wēi), 差(chà)” expressing the sense of "little”; in scope adverbs: “都(dōu), 了(liăo), 初(chū), 全(quán), 略(lüè), 差(chà), 总(zǒng), 顿(dùn)” expressing “all included”, “通 (tōng), 齐(qí)” expressing the same; “正(zhèng), 政(zhèng), 劣(liè), 只(zhǐ), 单(dān), 空(kōng)" expressing “the unique”; in time adverbs: “经(jīng)” expressing “already”, “行 (xíng), 欲(yù)” expressing “shall, will”, “顿(dùn), 登(dēng)” expressing “immediately”, “便 (biàn), 仍 (réng), 寻 (xún)” expressing “presently”, “仍 (réng), 频 (pín), 累 (lěi)” expressing frequency, “每(měi), 动(dòng), 经(jīng)” expressing “every”, “向(xiàng), 比 (bì), 近(jìn), 当(dāng)" expressing past nearness; in modal adverbs: “忽(hū), 猬(wèi), 奄 (yăn)” expressing “suddenly”, “唐(táng), 空(kōng), 坐(zuò)” expressing “in vain”, “幸 (xìng)” expressing “proper, appropriate”, “偶(ǒu)” expressing “by chance”, “垂(chuí), 仅 (jìn)” expressing “almost”, “故 (gù), 还 (huán), 方 (fāng), 仍 (réng)” expressing continuation, “暂(zàn)" expressing "the temporary”, “也(ye)” expressing "also, too", “互 (hu)" expressing “each other”; mood adverbs: “定(dìng)” expressing “certainly”, “脱(tuō)” expressing “or”, “颇(pō), 可 (kě)” expressing interrogation, doubt (Liu Jian, Jiang Lansheng, Bai Weiguo, Cao Guangshun, 1992: 245), “将(jiāng), 宁(nìng)” expressing speculation, “将(jiāng), 更(gèng), 可(kě)” expressing rhetorical questions, “仰(yang)” expressing “make, order”; deitic adverbs “相(xiāng), 见(jiàn)”. Most of these new adverbs continued to be used till later times and became an important constitutive part of the adverbs in the Early Modern Chinese. Besides, the new suffixes “自(zi)” and “复(fü)” were in wide use, greatly enhancing the word-formation of adverbs. Thirdly, in agreement with the increase of two-syllable words, the new and old adverbs are often two-syllabled. They could be divided into two groups: one was the combinatory use, and the other compound words. The former also included two types: one was the compound use of synonymic adverbs, the other the frozen phrases in use. The latter were divided into two types: one was composite words with suffix “自(zì), 复(fù), 尔(ěr), 然(rán)”, and lianmianci ${ }^{\text {(2) with }}$ the new senses of an adverb. This way of two-syllable formation of an adverb had a great impact on the the later periods of the Chinese language.

\subsection{Prepositions, conjunctions and auxiliaries}

The development of prepositions, in the main, lays in the replacement of the old forms by new ones. Firstly, the highly complicated system of prepositions in ancient time tended to become more simplified and regulated. Some prepositions with the same meaning and function were eliminated, while more frequently forms used were retained. Secondly, new

\footnotetext{
(2) Chinese words consisting of two characters, often alliterated or rhymed (as “仿佛(făngfú), 逍遥 (xiāoyáo) etc.").
} 


\section{Liu Shizhen Ji Yunxia}

prepositions appeared, some of which sprouted in ancient time but developed and were in wide use in Middle time, and some appeared and only began to be used in Middle time. These new prepositions were: in time-place prepositions “在(zài), 着(zhuó), 垂(chuí), 夹 (jiā)”, expressing “at, in”, “投(tóu)” expressing “attain to, arrive at”, “向(xiàng), 当(dāng), 对(dui)” "expressing “toward”, “扶(fú), 寻(xún)” expressing “along”, “坐(zuò)” expressing

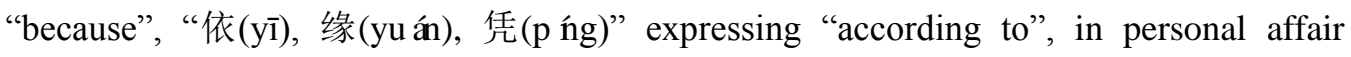
prepositions: “向(xiàng), 对(dui)” expressing “towards”, in cause prepositions: “共(gòng), 将(jiāng), 合(hé), 连(lián)” expressing “with”, and “被(bèi)” expressing passive "by”.

The use of conjunctions had four obvious characteristics. Firstly, some conjunctions with the same meanings disappeared and the whole system of conjunctions tended to be simplified. Secondly, a group of new conjunctions and the new-born conjunction suffix “复 (fü)" came into being. Most of the former appeared and were in use in this period, while a few sprouted before this time, were in wide use in this period, and few sprouted in this time and were used by the periods of Tang and Song. These conjunctions were: “共(gòng), 将 (jiāng)” expressing juxtaposition “and”, “并(bìng), 加 (jiā)” expressing progression “furthermore”, “为(wéi)” expressing choice, “or”, “还(hái), 但(dàn)” expressing transition, “but”, “由(yóu), 因(yīn)” expressing cause and effect, “because”, “so that”, “脱(tuō), 自 (zi)” expressing assumption, “if”, “就(jiù), 正(zhèng), 便(biàn), 自(zì)” expressing concession, "even if". Besides, the adverb suffix “复(fü)" now became used as the suffix of conjunction as a result of analogy. Thirdly, conjunctions with the same meaning used to be used in a compound in previous periods, and this usage further developed in the Middle Time. These were divided into two groups: the old conjunctions and the old-new conjunctions. The former included: “若其(ruòqí), 如其(rúqí), 苟其(gǒuqí), 假其(jiăqí), 设其(shèqí), 傥其(tăngqí), 假使(jiăshǐ), 假令(jiălìng), 若令(ruòlìng), 设令(shèlìng), 设 使(shèshǐ), 借使(jièshî), 若使(ruòshǐ), 傥若(tăngruò)” expressing assumption “if”, “虽使 (suīshǐ), 虽 令 (suīlìng), 虽 其 (suīqí), 纵 使 (zòngshî), 纵 其 (zòngqí), 即 使 (jíshî)” expressing concession, “though”. The latter included: “脱若(tuōruò), 脱其(tuōqí), 如脱 (rútuō), 若脱(ruòtuō)” expressing assumption “if”, “就使(jiùshǐ), 正使(zhèngshī), 就令 (jiùlìng)" expressing concession "though". Fourthly, some phrases used in a fixed way became gradually condensed into two-syllable conjunctions, mainly “于是(yúshì), 所以 (suǒyǐ), 因此(yīncǐ), 万一(wànȳi), 不但(bùdàn)”. These compound conjunction phrases, with the suffix “复(fü)”, were mainly used to express assumption and concession, “若复 (ruòfù), 虽复 (suifù), 纵复 (zòngfù), 假复 (jiafù), 况复 (kuàngfù), 脱复(tuōfù), 就复 (jiùfù), 正复(zhèngfü)”, “为复(wéifù)” were used to express choice “or”.

Changes in auxiliaries, in the main, could be seen in three aspects. Firstly, as the grammatical structure became stricter, the mood auxiliaries widely used in ancient time now tended to die out, only a small part of which stayed in common use. Secondly, the few 
new mood auxiliaries at the end of the sentence were used occasionally, e.g. “那(nă)” expressing doubts or rhetorical question. Thirdly, such auxiliaries as “看(kàn), 将(jiāng), 都(dōu), 著(zhuó)" were in the course of development and change. (Liu Jian, Jiang Lansheng, Bai Weiguo, Cao Guangshun, 1992:58).

The appearance and the development of prepositions, conjunctions and auxiliaries laid the foundation for their further mature development in the Dynasties of Tang and Song.

\subsection{Word- formation}

The general tendency of word-formation in Middle Chinese was the disyllabification of a word. The chief factor leading to the increase of two-syllable words was the Chinese translation of foreign books and the requirement of the fineness and accuracy in forms. The characteristics of word-formation in this period were as follows. First, foreign words (i.e. chiefly those from the phonetic renderings of the words in Buddhist Scripture in Chinese translation) led to the production of a lot of two syllable words formed with disyllabic single words. Second, the use of the derivative method (i.e. an affix added to a root) and the foreign words (i.e. chiefly those from the Chinese paraphrases of Buddhist Scriptures) led to the production of a lot of two-syllable compound words. After the Song Dynasty, with this development, phonetic simplification led to the production of a lot of homonyms, and by differentiation of homonyms by disyllabification, the disyllabification developed more rapidly.

\subsection{Word order}

The changes in word order, in the main, lay in five aspects. Firstly, the interrogative pronoun functioning as an object was moving from pre-positioning to post-positioning. Generally speaking, new interrogative pronouns acting as objects were chiefly post-positioned while the old interrogative pronouns acting as objects could often be post-positioned. Secondly, in negative sentences the phenomena of pre-positioning of the pronouns as objects further decreased, and post-positioning was gradually becoming the predominant word-order. Not only could the new pronouns as objects of negative sentences not be pre-positioned, but also most of the old ones could not be either. Thirdly, in numeral-quantifier phrases, the structure of quantifiers before numerals gradually stopped being used, and the word-order of numerals before quantifiers became dominant. In the combination of a numeral-quantifier phrase with a noun phrase, the numeral-quantifier phrase comming before the noun phrase was gradually becoming the norm, while the practice of noun phrase began to be constrained. Fourthly, the prep-object structure, which expressed the position of the agent of action performed by the predicate verb, was, in the main, positioned before a verb, so the pre-object structure consisted of not only the new position preposition but also the old one, a change from the language of the Pre-Qin period. Fifthly, the prep-object structure acting as an instrument being positioned before the verb 


\section{Liu Shizhen Ji Yunxia}

became a general rule, and post-positioning was very rare.

The five word orders listed above, representing the developmental direction, gradually became the basic fixed word order of Chinese after the periods of Tang and Song.

\subsection{Determination (Judgment )sentences}

The main characteristic of the development of the determination sentences in Middle Chinese was that the determinator “是(shi)” overall began to be mature. “是(shi)" sentences became widely used and gradually replaced the determination sentence of subject + predicate, a typical sentence pattern of determination sentences in Old Chinese. This could be concluded from the following aspects. First, looking at the sentential composition, the sentential-end “也(ye)” gradually dropped out, which showed that the character “是 (shi)" already took the role of expressing judgment. Meanwhile, a series of omissions occurred, and the subject and object could be omitted respectively, or even both omitted at the same time, as long as this did not affect the meaning. Besides, the structural elements of “是(shi)" sentences tended to become more complicated. Its subject could consist of a position phrase, a verb or a verbal phrase, and even a subject-predicate phrase, etc. The form “是(shi)" could be modified by adverbs, adjectives or auxiliaries, and its objects could be a verb, a verbal phrase, and an adjective, or an adjectival phrase, a subject-predicate phrase, etc. Second, looking at the expression of meanings, the “是(shi)" type judgment sentences gave rise to the extended usages of confirming facts or explaining reasons and helped to produce the mood of adverbs or conjunctions. Third, the negative forms of “是(shì)”, i.e. “非是(fêi shì), 未是(wèi shì), 不是(bù shì)” already appeared (cf. Tang Yuming, 1992:397; Wang Weihui, 1998:133).

The “是(shi)" type judgment sentences matured and further developed in the Middle Time, thus expressing richer meanings in early Modern Chinese.

\subsection{Interrogative sentences}

Two important changes were notable in interrogative sentences in Middle Chinese. Firstly, some interrogative sentences without the use of interrogative words appeared, a phenomenon especially obvious in the works close to speech, for speech transmitted the interrogative mood often with the help of context and tone; no interrogative words were necessary. Secondly, some new interrogative pronouns, alternative conjunctions and measure-inquiring words appeared, the use of which yielded new forms. The new interrogative pronoun was the character “那(nă)”, and it was often combined with auxiliaries “得(dé), 可(kě), 能(néng)” and used in rhetorical questions and in asking questions. The new alternative conjunction “为(wéi)" and its compound forms “为是 (wéishì), 为复 (wéifù), 为当(wéidang)" often appeared at the very beginning of each of the alternative clauses, and were used in a coordinated way but rarely alone. Sometimes it was common practice to put one of these compound forms only at the beginning of the 
second clause. When used, they seldom coappeared with the sentence-end auxiliaries of mood. The usage of duplicate questions in either-or questions had a new development: it could either consist of a narrative sentence in which negatives “不(bù), 否(fǒu), 未(wèi)” were put at its end to indicate the negation, or of a judgment sentence in which negative adverbs “非(fêi), 不(bù), 否(fǒu)" were put at its end to indicate the negation. The new words used to inquire measure were: “多少(duōshăo), 几许(jǐxǔ), 几多(ǰ̌duō)” inquiring amount, “何当(hédāng), 早晚 (zăowăn)” inquiring time, “远近 (yuănjìn)” inquiring distance, etc.

In all the above-mentioned interrogative patterns, the alternative conjunction "为(wéi)" and some of the words used to ask about measures were characteristic for Middle Chinese. The usage of “那(nă)" to ask a question went on till the later times, and the negative adverbs at the end of the duplicate questions developed and changed into the sentence-end auxiliaries of mood after the Tang and Song Dynasties.

\subsection{The predicate-complement construction}

In Middle Chinese, this construction was mainly inherited from the usage of ancient Chinese, but the resultant complement, direction complement and quantity complement showed some new developments. In the construction expressing a result, if the predicate was a transitive verb and the complement an intransitive verb, the usage of this construction at this period became more complicated, regarding whether the predicate and its object were overt or covert, and positioned before or after the complement. While the predicate had an object, the object was usually positioned after the complement, but in some cases the objects was positioned between the predicate and the complement, in a pattern of the object separating the verb from the complement. When the predicate took no object, the intransitive verb acting as the complement was in the main to express the result (state) of the action performed by the predicate. If the predicate was a transitive verb and the complement an adjective, the usage of this construction in this period varied as to whether there was an object or not, or if the object was positioned before or after the complement. When the predicate had an object of its own, the object was most often put after the complement, with only a few examples of being put between the predicate and the complement. When the predicate did not have an object, the adjective acting as the complement tended to indicate the nature of the consequence of the predicate (action). By this time, the resultant complement with the character “得(dé)" also began to sprout, but its nature was still not stable enough, and examples of its use were, relatively speaking, rare. However, it was not only the usage of expressing the result by the complement with “得 (dé)" that matured by the times of Tang and Song, but also the newly developed usage of expressing the possibility. The fact that in this construction indicating the direction the object was put between the predicate and the complement, and the predicate (i.e. transitive 


\section{Liu Shizhen Ji Yunxia}

verb) was combined with “来(lái), 去(qù)” respectively (two directional verbs) was extremely rare in ancient time, but a new grammatical phenomenon in the Middle time. Moreover, the verbal-classifier complements were also relatively common, a result of the initial maturity of verbal-classifiers in this period.

\subsection{The Passives}

There were two kinds of remarkable development of the passives in Middle Chinese. Firstly, the passive “为....... 所(wéi ...suǒ)" was in unprecedentedly wide use, and on the basis of “为....... 所(wéi ...suǒ)", some changes which had not been seen in ancient time took place. They were: the combination of the “为....... 所(wéi... suǒ)" construction with the complement construction, the frequent occurrence of the constructions “为...... 所见 (wéi..... suǒjiàn)......" and “为......之所(wéi...zhī suǒ)”, all reflecting the difference from ancient Chinese. Secondly, the "被(bèi)" passive matured, its structure having become more complicated and various. In addition to the typical passive "被(bèi) + agent + verb", some other constructions were formed, such as: the "被(bèi)" construction with the agent omitted; the combination of the "被(bèi)" construction with the complement construction; the verb in the passive voice in the "被(bèi)" construction taking an object; “被(bèi) + agent+ 所(suǒ) + verb” and “被(bèi) + agent + 之(zhī) + 所(suǒ) + verb”, etc.

The “被(bèi)" construction was strongly colloquial, so even though the “为...... 所 (wéi......suǒ......)" construction was still dominant in the written language of this period, it could only be gradually replaced by the "被(bèi)" passive in oral language after the periods of Tang and Song.

\section{Historical position of Middle Chinese Grammar}

The paper gives a brief description of the main features of development in Chinese grammar in the Middle Time. The presented laws have been generalized from the oral corpus coming from various books appearing during a period of 600 years, i.e. from the Eastern Han Dynasty to the Sui Dynasty. As far as the overall features of the grammar reflected in the books are concerned, it can be said that the grammar was still based on its inheritance from the ancient usage, and that grammatical forms of ancient Chinese were still used. A few changes occurred, reflected mainly in the tendency of the regulation of pronouns and functional words, in addition to some new sentence patterns. Even in the books from this period which were close to speech, e.g. books containing anecdotes, collections of informal essays, books on agriculture and medicine, miscellanies, and translations of Buddhist Scripture, the grammatical features of Middle Chinese were a more typical, concentrated reflection of the above-mentioned changes. It follows that it is not necessary to highly evaluate the grammar of Middle Chinese. However, there is also the fact that the grammar was in the course of gradual changes and development, and the 
oral information revealed from the above-mentioned respects of morphology and syntax anticipated that Chinese grammar would undergo a great change, and the history of grammatical development has proved that it is these oral materials that are the origin of language changes into the Early Vernacular. In particular, with the influence of various new forms of grammar on later Chinese, the development of the grammar of Middle Chinese did lay the solid foundation for the grammatical changes in the Dynasties of Tang and Song, and it was in this very period that many grammatical phenomena which prevailed in later generations began to sprout. It follows that the historical role of Middle Chinese grammar should not be underestimated. The grammatical development in this period suggests that the Middle Time should be the pivot of changes for Chinese grammar from the ancient to the early modern, playing the key role of inheriting from the old and initiating the new, therefore occupying a very important position in the history of Chinese grammar.

\section{References}

Chen Chengze. 1982. A Draft of Chinese Language. [M] Shanghai: The Commercial Press.

Chen Mengjia. 1956. A Survey of Yin Ruins Oracle Inscriptions (Chapter III: Grammar). [M] Beijing: The Science Press.

Ding Shengshu. 1935. Explanations on negatives “弗(fú), 不(bù). [A] In the Collected Papers of Historical Language Institute in memory of Mr. Cai Yuanpei' $65^{\text {th }}$ Birthday (the $2^{\text {nd }}$ book). [C] Academica Sinica.

Fang Yixin \& Wang Yunlu. 1993. A reader of Middle Chinese. [M] Changchun: Jilin Education Press.

Guan Xiechu. 1953. A Grammatical Study on Yin Ruins Oracle Inscriptions. [M] Beijing: The Science Press.

Guo Xiliang. 1997. A collection of the papers on the history of Chinese Language. [M] Beijing: The Commercial Press.

Karlgren. 1940. The study of Chinese phonology. [M] Beijing: The Commercial Press.

Liu Jian, Jiang Lansheng, Bai Weiguo, Cao Guangshun. 1992. The study of function words in early modern Chinese. [M] Beijing: Language Press.

Liu Shizhen. 1992. The historical grammar of the dynasties of Wei, Jin, and the Northern and Southern Dynasties. [M] Nanjing: Nanjing University Press.

Liu Shiru. 1965. The study of quantifiers in the dynasties of Wei, Jin, and the Northern and Southern Dynasties. [M] Beijing: Chung Hwa Book Co.

Lü Shuxiang. 1985. Deitics in the early Modern Chinese. [M] Shanghai: Xuelin Press.

Lü Shuxiang. 1984. Interpretations of the two auxiliaries “在(zài), 著(zhuó)” in Jingde Chuan Deng Lu.

[A] In Lü Shuxiang: A Collection of Papers on Chinese Grammar.[C] Shanghai: The Commercial Press. Ma Jianzhong. 1983. Ma's Grammar. [M] Shanghai: The Commercial Press.

Ohta Tatsuo. 1991..A general survey on the history of Chinese Language. [M] Chongqing: Chongqing Press.

Shimura Lyoji. 1995. The study of the history of Middle Chinese grammar. [M] Beijing: Chung Hwa Book Co.

Tang Yuming. 1992. A survey of “是(shì)” judgment sentence. [J] Zhongguo Yuwen (Chinese Language). No.5.

Ushijima Tokuji. 1971. Papers on Chinese Grammar (The Middle Chinese Volume). [M] Tokyo: Taishukan Publishing Co., Ltd.

Wang Li. 1980. A Draft about the History of Chinese (Volume II). [M] Beijing: Chung Hwa Book Co. 


\section{Liu Shizhen Ji Yunxia}

Wang Li. 1980. Copulas in the Chinese Grammar. [A] In Wang Li: The Collections of Long Chong Bing Diao Zhai Book I ( A collection of papers on Linguistics). [C] Beijing: Chung Hwa Book Co.

Wang Weihui. 1998. The time when copula “是(shi)” became mature. [J] Zhongguo Yuwen (Chinese Language). No.2.

Xu Jialu, Wang Fuxiang, Liu Runqing. 1996. The State of Arts and Prospect of Chinese Linguistics. [M] Beijing: Foreign Language Teaching and Research Press.

Yang Shuda. 1980. Senior Chinese Grammar. [M] Shanghai: The Commercial Press.

Zhang Shizhao. 1913. Junior Chinese Grammar. [M] Shanghai: The Commercial Press. 